\title{
Accepting the 'Other': immigrants in Israeli children's literature - a case
}

\section{study}

\author{
Prof. Moshe Yitzhaki \\ Department of Information Studies \\ Bar-Ilan University \\ Ramat - Gan, ISRAEL 52900 \\ yitzhm@mail.biu.ac.il
}

Keywords: Children's literature, Immigrants, Acceptance, Israel

\section{Introduction}

Israel is known as a typical immigration country, to which millions of people have immigrated throughout the last 130 years. The various problems encountered by immigrants in a new country, regardless of its geographical location, have been documented in detail by sociologists and anthropologists as well as by writers of novels and children's books. Inevitably, there are considerable social, economic, cultural, and sometimes religious differences between the immigrants and veteran residents. Much of the new-comer's resources are devoted to overcoming these difficulties Admittedly, a negative attitude towards new-comers has probably been a natural human reaction, especially if the latter differ in color, culture, customs and life habits. The incoming stranger is perceived as a threat to the existing society, its cohesion, values and hierarchy. When these differences couple with fears of competition over jobs, housing etc., the negative attitude, intensifies, and may lead to alienation, derision, rejection, and sometimes even to aggression and violence (Regev, 1990). However, in the special case of Israel certain unique factors were supposed to counter these natural human emotions. Many Israelis view the last century's immigration to the Holy Land not merely as a migration of people, but as the fulfillment of an ancient biblical prophecy, a crucial step towards the ultimate redemption. Thus, the successful absorption of immigrants in the Holy Land is also considered a religious duty, besides serving to strengthen the young country.

An existing population of 600,000 in 1948 had to absorb millions of immigrants, whose absorption often involved economical, sociological and psychological problems, resulting of mentality and culture gaps.

The huge immigrants waves following statehood exposed a discrepancy between the official government policy which considered immigration the most important national task, and the indifference of many people.

In the course of the mass immigration those responsible for their absorption developed negative stereotypes and a patronizing attitude, considering the new-comers inferior in culture, needing to discard their former tradition and customs, and adapt the surrounding culture. Ignoring immigrants different sociological and cultural background, the absorbers decided to determine their new value system and to reeducate them. The worst 
psychological problem for immigrants from developing countries was the disintegration of the traditional patriarchal-family framework, and the confrontation with modern competitive reality (Naor M \& Giladi D, 1990).

\section{Literature review}

Previous studies have investigated the question what are the images of certain minorities or sectors of society, as reflected in children's literature. Thus, several studies explored the image of the American Indians (Abel, 1973), Afro-Americans and Hispano-Americans(Blatt, 1968) in American children's literature; others probed the reflections of Jewish culture (Daniels, 1970). Still others studied the reflected images of women, girls, fathers, sexism and sexual bias (Stewig, 1973; Tate, 1973) as well as moral and ethical values (Lowry, 1968). Anderson (1994) published a guide for librarians and teachers which lists over 700 fiction books dealing with immigrants in the United States. The few studies in Hebrew usually deal either with one or a few stories only.

\section{Purpose of the study}

The purpose of the present study was to analyze the content of some Israeli children's books dealing with immigrants and immigration and published in different periods since 1948, in order to determine the image of immigrants and immigration reflected in these books, and the realism of that image.

\section{Methodology}

A survey of Hebrew children's literature found at least fifty books, mostly published during the last 40 years, in which immigrant problems were the central theme. The content and plots of some of them were analyzed to enable comparison of the various descriptions regarding immigrant expectations, veterans' attitudes towards him, his reaction and the end of the plot.

\section{Findings and discussion}

While the following conclusions relate to most books studied, due to time constraints, the examples and citations are limited, to a few representing books only, each written in a different year and describing different situations.

Only few books describe purely positive attitudes on the part of the settled-population (i.e. veterans), with no mention or hint of any negative emotions. Apparently, these books paint an idealistic picture, expressing wishes of their authors, depicting reality as they wanted it to be. The vast majority of the books, however, describe negative attitudes of the existing population towards the new-comers, such as: condescension, disrespect, contempt, arrogance, suspicion, social hostility, stigmatic outlook, prideful segregation, degradation, humiliation, etc. In fact, many veterans were sincerely willing to help the immigrants and ease their difficult process of absorption in a new country. However, they were also convinced they knew best what was good for the new-comers, and thus wanted them to change and to adopt the local culture and customs, strange and alien as they might seem. Sami Michael's book Tin Huts and Dreams exemplifies many of these attitudes and their effect on the immigrants children. Shimeon lives with his parents, immigrants from Iraq, in the 'maabara', a temporary settlement of tents and tin-huts, many of which were hastily erected all over the country, during the years of mass immigration (1948-52) (Lisak, 1993). Its inhabitants complain: "They have thrown us into tents and tin-huts full with mice and 
cockroaches and say this is the Promised Land...". Seeing his mother digging futilely with a defective pick-axe, Shimon recalls with yearning and nostalgia past days in Iraq, when his wealthy family celebrated holydays in joy and comfort. "You are crazy" he screams at her, but she turns to him and quietly says: "If I sit all day in the tin-hut I'll go crazy. Your father is also afraid he'll go crazy. He is only 50 and already too old to be given a job. So he sits in the cafe, having no money to pay even for a cup of tea. What should I do?"

A Chicken for Atonement, written by Eli Amir, indicates that these traumatic experiences were not limited to immigrants living in cities and towns, but happened also to youngsters who were taken in the early 1950's from the 'maabara' to get a 'better' education in a Kibbutz. Culturally, the children were very different. The Kibbutz members did not conceal their contempt for the children's oriental celebration and the latter reacted by stubbornly clinging to each other and to their traditional customs. The kids themselves felt torn between two different and conflicting worlds: they had lost much of the connection to their family traditions and culture but still did not feel part of the local culture, like the kibbutz-born children. As in Sami Michael's book, the boy Nuri feels that the immigrants from Muslim countries are scorned by the 'sabras' (native Israelis), who consider them primitive and lacking culture. Thus, naturally, the kibbutz members feel superior, and try to reeducate the new-comers, and mould them to conform to kibbutz norms and become real kibbutzniks like themselves (Raz, 1990).

Most books stress the stigmas and prejudices of the veterans towards the new-comers, being a frequent cause of friction and tension. When Shimon, Sami Michael's book hero, offers his service as a porter to a woman, she eyes him suspiciously and says: "You are from the 'maabara, aren't you?", because for her Maabara dwellers were merely a rabble of uncivilized refugees, of which one should be beware. An old man hit the sidewalk with his cane, saying: "Somebody should teach them to behave like humans", and "immediately two decent guys appeared, who politely rushed to save the poor woman from the insulting hoodlum. One of them grabbed Shimon's hands from behind and the other clutched his neck, asking the woman: "what did this bastard do to you?". The woman was not mean and she pitied the innocent boy, but being so upset, she was unable to talk. Later, Shimon encounters similar attitude when he returns a stolen carpet (not by him) and overhears a woman saying: "They have ruined the whole neighborhood... thieves... criminals...nothing can be left outside unattended...". To be sure, her son disagrees with his mother prejudice, but she does not listen to him. In fact, most stories include some positive veterans, who favor the immigrants, befriend them, and try to convince others that the new-comers are decent people and deserve better treatment.

Another scene illustrates the hurting suspicion and contempt towards the new-comers. Daabul, Shimon's friend, declares: "l'm going to leave your Israel!". "You are an idiot" - says Shimon. "Yes, I'm really an idiot"- laughed Daabul bitterly. "This morning I suddenly felt an urge to go into a bookstore and browse. The store-owner blocked the entrance with his arms, asking in a threatening tone what I want. I saw from his look that he was sure I had never held a book in my hands. So, I purposely told him in English that I wanted an English book for my horse here and left angrily". Shimon tries to calm his friend: "It makes me angry too, but some day they will realize that we are not bunch of nobody's". "Don't you understand said Daabul -they don't want us here....and we are tired. Do you know why? - everywhere I 
have to convince people that I'm no cheater, no idler, no idiot, and this is the most difficult thing to do, to convince idiots that you are not an idiot".

Even the government official responsible for the maabara is plagued with these biases: "Sergeant - he says to the policeman - you are new here and are not familiar with people here. They do not lie purposely, but they are like children, naive and ignorant. They have wild imagination, unable to distinguish between truth and fantasy."

Another common motive in these books is the feeling of shame and humiliation of parents and especially children, because of the steep decline in the father's job status in the new land. Before his immigration the father held a dignified profession, and was widely respected, but here he was reduced to menial labor, which he never imagined before. It is a common phenomenon among immigrants. Following the Perestroika and the Glasnost, when the gates of the former Soviet Union were opened, over one million Jews immigrated to Israel, many of them highly educated. But, very often their diplomas were not recognized and so it was common to see physicians and doctors working in street cleaning until they passed the local exams.

The painful and negative experiences encountered by the immigrants naturally lead to great disappointment. They harbored high expectations, of coming to the promised homeland, but eventually realized that they have to live a long time in a temporary maabara, in poor physical conditions, in tents and tin-huts.

Understandably, aimed at children as target-population, most books analyzed do not elaborate on parents' jobs, their feelings, sufferings and problems, but rather detail the emotional problems and sufferings of children in adjusting to a new country and society. Most books emphasize the deep disappointment of the children following the cold and unfriendly welcome of their classmates. Expectedly, they respond by longing for their former country, where they enjoyed respect, status, friends, and wealth, although they know returning is not a realistic option. Consequently, some sink into despair, regretting their coming to the land: Dudik, the boy immigrating from Romania in 1950 (in: To Be Like Everyone, by Moshe Granot) and Marusia, the girl arriving from Russia in the 1980's (in: Marusia, Marusia, by Ze'ev Vardi) despair in a moment of weakness and resign themselves to the current situation and to remaining outsiders forever.

Most books describe the educational staff as combating against the alienation and negative attitudes, at school and outside. Many plots include a similar scene: the principal or teacher enter the classroom, tell the pupils about the new-comer and ask them to be nice and helpful to her/him. This description is a realistic one, but admittedly there has probably been a considerable discrepancy between the educational-national messages transmitted by leaders and educators, concerning the importance of immigration to the country, and the daily encounter of the veteran population and the new-comer (Regev, 1990). In most plots the local children, or at least some of them, do not comply, but rather mock and laugh at the new pupil and exclude him from their games. Nuri, in Eli Amir's book, says: "You, veterans, have built the country for us. We love you and admire what you have done here...but I must tell you...that in one thing you have failed, your children don't know how to welcome newcomers. They patronize, degrade and insult us."

Interestingly, many authors chose to set the plot in a kibbutz, where in reality many immigrant youth groups were sent by the authorities for a combined program of education 
and work. The reasoning was that the process of acculturation and reeducation would be easier in an egalitarian society, whose members are educated and highly motivated, as far as national missions are concerned. The kibbutz society was thus chosen as a melting-pot, which would mold the young immigrants into the desired model of the new Israeli (Raz, 1990). This was somewhat successful, but too often at the expense of abandoning old traditions, customs and family ties.

At first glance it is a bit surprising to realize from these stories, rooted in reality, that the negative attitude towards immigrants prevailed not only among city and town children, but also among kibbutz ones, whose education emphasized equality, brotherhood and friendship, and whose members were considered, from certain aspects as the country elite, holding high positions. The explanation is probably that a child is a child, whether in a town or in a kibbutz, and the feelings of superiority, emanating from their parents, contributed too. Similar complaints, not unrealistic, could be referred also against non-kibbutz children, whether in rural settlement (moshav) or in town. The 'moshav' children in Granot's book do not accept Dudik, the young immigrant from Romania, to their group and he suffers social segregation. Likewise, the 'moshav' children in Yitzhak Noy's book (The Hill of Black Irises) object to the North-African immigrants building their homes on the adjacent hill, because the lovely irises will disappear... In fact, some of the adults at this moshav also look down at the new-comers, claiming they are dirty, primitive and lazy.

Many studies and media reports confirmed difficulties of adjustment and feelings of alienation and isolation prevailing among immigrants' children. A recent study found that about twothirds manifested signs of distress, typical to cultural shock following immigration. They spoke about longing for their former country, complaining about social segregation and reduced efforts in school. Indeed, some of the obstacles confronting these children in the educational system are almost inevitable. The need to learn a new language, the cultural shock and the painful process of adjustment of the whole family adversely affect successful integration at school. Succeeding in such circumstances, requires not only talent, but also a strong will power and much willingness to invest in learning, and ultimately many do succeed.

In most books the plot reaches a stereotypical happy ending when eventually, sometimes following a certain event which breaks the barriers between the new-comer and his classmates, they apologize for being so nasty and accept her or him as an equal peer. Marusia, in Vardi's book (Marusia, Marusia), differs from her brother, Volodia, who easily adjusted to the surrounding due to his almost complete command of Hebrew and his outstanding ability in playing football, thus immediately becoming everyone's friend. Marusia's period of adjustment was long and painful. Only the friendship with Dina from the very first day, helped her overcome the teasing of some classmates, although others are friendly. More than once she returns from school angry and desperate, declaring she would never go back to that awful class. The turning point comes one morning when a shy blackskinned Ethiopian boy is introduced by the teacher to the class, and nobody volunteers to sit next to him, except Marusia, who becomes his main tutor and helper. Marusia's position in her class greatly improves from then on and most of her classmates became real friends. One day the whole class goes enthusiastically to the airport to welcome a large group of Russian immigrants. Similarly, Michael's book ends with the mother saying proudly: "All 
gates have been opened", and Nuri, in Amir's book, gratefully hears Dulek, the kibbutznik, complementing the group of immigrant boys who came to learn and work in the kibbutz.

\section{Conclusions}

1. The children described in these books immigrated to Israel from various countries around the globe. Assuming that most authors describe true personal experiences, testifying to events they or others in their proximity have undergone, one may conclude that the common view attributing the negative attitudes to the Afro-Asian origin and different color, is not entirely correct, since also western and East-European originated immigrants encountered similar negative attitudes, probably due to the differences in culture, customs and mentality.

2. The negative attitude towards immigrants was not limited to any specific period but characterized almost all periods of immigration to Israel, even the British Mandate period, long before the establishment of the Jewish State.

3. A content analysis suggests that in daily reality all these factors interact, and it was not easy to practice in reality the officially-preached positive attitude towards the immigrants. Hence the ambivalent feelings prevailing in life and described truthfully in the literature.

4. It is worth noting that all books analyzed in the present study include an educational message, sometimes implicit, that the negative attitudes towards immigrants stem from biases and prejudice, and are wrong, immoral, unfair and unjustified. Each individual should be treated only according to his deeds and behavior, rather than his color or origin.

5. Those immigrants who remained steadfast, struggling bravely against the unpleasant environment and conditions, finally overcame the obstacles and were successfully absorbed in the new country.

\section{References}

Abel MB (1973) American Indian Life as Portrayed in Children's Literature. Elementary English 50: 202-208.

Anderson V (1994). Immigrants in the United States in Fiction: A Guide to 705 Books for Librarians and Teachers, K-9. Jefferson (NC), McFarland.

Blatt GT (1968) Mexican-Americans in Children's Literature. Elementary English 45: 446-451.

Daniels L (1970) 34th Man: How well is Jewish Minority Culture Represented in Children's Fiction? School Library Journal 17: 38-43.

Lisak M (1993) The Immigrations. Encyclopaedia Hebraica, State of Israel. vol. 6 (2): 399 413.(in Hebrew)

Lowry HW (Apr.1968) A Content Analysis: Middle-Class Moral and Ethical Values in the Newbery Books. English Record 18.

Naor, M. and Giladi, D. (1990) The Land of Israel in the 20th Century; 1900-1950. Tel-Aviv, Ministry of Defence (in Hebrew) 
Raz H (1990) On the Topic of Immigration Absorption. Sifrut Yeladim ve-Noar, 17(1): 4851.(in Hebrew)

Regev M (1990) Society Against the Stranger and the new-comer. Sifrut Yeladim ve-Noar 17(2):21-25. (in Hebrew)

Stewig JW \& Higgs, M (1973) Girls Grow up Be Mommies. School Library Journal 19:44-49.

Tate JM (1973) Sexual Bias in Science Fiction for Children. Elementary English 50:10611064. 